\title{
Non-Manufacturing Medication Distributor
}

National Cancer Institute

\section{Source}

National Cancer Institute. Non-Manufacturing Medication Distributor. NCI Thesaurus.

Code C128542.

Parties other than the drug's manufacturer who distribute, sell, or transfer the drug for reasons other than filling a specific prescription. 